\title{
RUNOFF MANAGEMENT TECHNOLOGY FOR INTEGRATED DRY LAND AGRICULTURE IN JATINANGOR RESEARCH CENTER WEST JAVA, INDONESIA
}

\author{
Nurpilihan Bafdal", Sophia Dwiratna and Dwi R. Kendarto \\ Soil and Water Engineering Laboratory, Padjadjaran University \\ Jln. Raya Bandung, Sumedang Km. 21 Jatinangor 40563 \\ *E-mail: nurpilihanbafdal@yahoo.com
}

\begin{abstract}
I
ndonesia as a humid country has two climate seasons: dry and wet seasons. Decreased dry land agriculture productivity is due to a limited availability of water especially in dry season; while during the wet season, water from rainfall as a runoff couldn't conserve on the soil maximally. The potential runoff can, certainly, be utilized as an alternative water source in dry season. The main purpose of the present research is to manage runoff using technological means during the wet season for the dry seasons agriculture production. The research was conducted on dry land agriculture at Jatinangor Research Station, West Java, Indonesia. The research methods are survey, descriptive analysis and observations on potential runoff and prediction by using Rational Method, location mapping, rainfall analysis and crop water requirement analysis. The prediction analysis indicated that peak of runoff occurred in January was about $200.46 \mathrm{~m}^{3}$. This result is in line with the peak of rainfall occurred in the research station field $(297.94 \mathrm{~mm})$. The annual total potential cumulative runoff was $1160.05 \mathrm{~m}^{3}$; which indicates that runoff potential is an alternative source for irrigation water in the dry land. Analysis of the ratio of the catchment area to the area of cultivation shows that $\mathrm{C}$ : CA is 14.8. This means that in order to produce a monoculture of corn of $1000 \mathrm{~m}^{2}$ for 3 seasons in one year, it requires a $14.800 \mathrm{~m}^{2}$ of catchment area.
\end{abstract}

Keywords: potential runoff, dry land, agriculture, irrigation

Indonesia has very large dry land areas, reaching 148 million hectares, out of which the dry land suitable for agriculture is only 76.22 million ha (52\%), mostly located in the lowlands (70.71 million ha or 93\%) and the rest is in the highlands. Dry land for agricultural cultivation is spread in Sumatra (22.8 million ha), Java (5.6 million ha), Kalimantan (22.5 million 
ha), Bali and Nusa Tenggara (2.6 million ha), Sulawesi (6.6 million ha), Maluku and Papua (12.9 million ha) (Center for Soil and Agro-climate 2001 in Bafdal et al., 2013). There are several obstacles facing the development of dry land farming. One is the availability of water is limited to rainfall and long dry season. Integrated dry land farming relies heavily on the availability of water, land productivity and crop yield.

An effort to overcome this problem is to manage a concept of runoff technology as a harvesting runoff, especially during the wet season in order to meet the needs of water in the dry season. Prinz and Malik (2002) noted that when the rain water in the form of surface runoff are harvested and then directed to the agricultural area, this technique is called with runoff farming. Runoff Management Integrated Farming Design is basically a dry land agricultural landscape design that is based on the analysis of the ratio of the Catchment Area (C) to Cultivated Area (CA); how is the ratio C:CA impact irrigation water and water requirement of crops in dry season of the dry land agriculture.

\section{MATERIALS AND METHODS}

The research was conducted in the Dry Land Jatinangor Research Centre on an area of 2,144 hectares. The methods used are a descriptive analytical method; survey; mapping of location and field observations. Potential runoff that can be harvested from the land is calculated using the model of Rational Method. Runoff coefficient is determined by field observations of actual runoff using runoff plots, while area rainfall is calculated by using Thiessen Polygon Method. Analysis of topography and mapping was carried out to delineate the location of the catchment area, runoff storage in the pond and cultivation area. In summary, the research structure is shown in fig. (1).

\section{Observation}

The observations of the research are:

1. Physical Soil Properties

2. Rainfall of Research Center Area Analysis

3. Topography Condition

4. Actual Runoff Measurement and Runoff Coefficient

5. Potential Runoff

6. Design of Runoff Management Integrated Farming

7. Crop Water Requirement

8. Rainfall Design

9. Runoff Coefficient and Efficient Factors

10. Ratio of C:CA

Egyptian J. Desert Res., 65, No. 1, 1-10 (2015) 


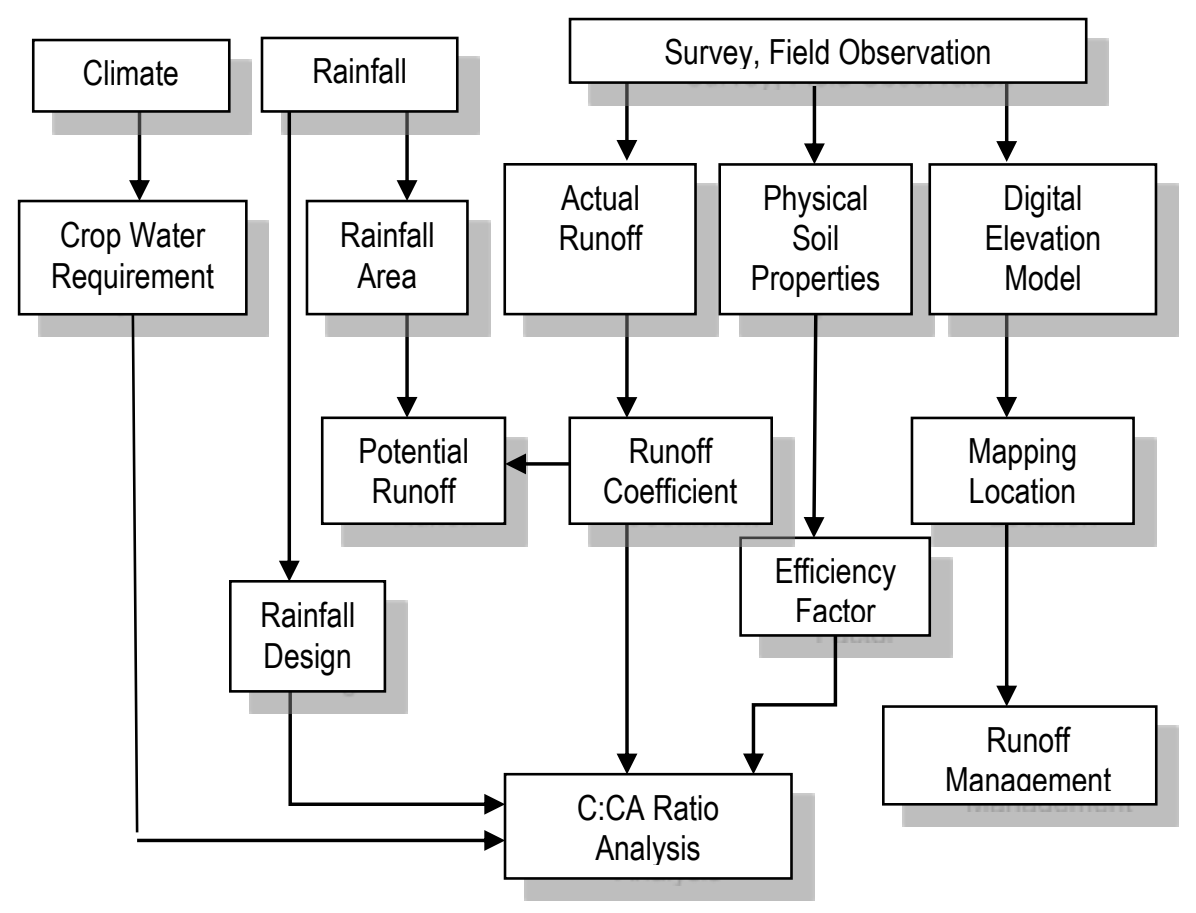

Fig. (1). The research structure.

\section{RESULTS AND DISCUSSION}

\section{Physical Soil Properties}

Research was carried out on dry land with intercropping system between annual crops, such as coconuts, and seasonal crops, such as corn, sweet potato and cassava. Based on field surveys, it is known that the land was managed by 17 farmers with dry land area of $700 \mathrm{~m}^{2}$ for each farmer. Soil types in the Jatinangor Research Center are inceptisol with soil physical properties shown in the table (1).

\section{Rainfall Analysis}

Rainfall Research Center analysis is calculated by using Thiessen Polygon Method. The results showed that the average of rainfall area in the Jatinangor Research Center (97\%) was influenced by rainfall measured at Station SPMK Pedca Padjadjaran and 3\% are affected by rainfall measured at Jatiroke Station. Rainfall area analysis showed that the average annual rainfall was $1879.69 \mathrm{~mm}$. The maximum monthly rainfall occurred in January $(297.94 \mathrm{~mm})$ and the minimum rainfall occurred at August (20.12 $\mathrm{mm}$ ) as shown in fig. (2). 
Table (1). Physical properties of soil.

\begin{tabular}{|c|c|c|c|}
\hline Parameters & Result & $\begin{array}{c}\text { Indicat } \\
\text { or }\end{array}$ & $\begin{array}{l}\text { Range of } \\
\text { parameters }\end{array}$ \\
\hline Bulk density $\left(\mathrm{g} / \mathrm{cm}^{3}\right)$ & 1,13 & Low & $1.1-1.6$ \\
\hline $\begin{array}{l}\text { Water content (\% } \\
\text { volume) }\end{array}$ & $\begin{array}{l}\text { pF } 2.54(38.78) \\
\text { pF } 4.2 \quad(28.2)\end{array}$ & - & - \\
\hline Porosity (\%) & 57.44 & Good & $50-60$ \\
\hline Permeability $(\mathrm{cm} / \mathrm{h})$ & 0.43 & $\begin{array}{l}\text { Mediu } \\
\mathrm{m}\end{array}$ & $0.20-0.8$ \\
\hline Soil texture (\%) & $\begin{array}{c}\text { Sand (8.92) } \\
\text { Silt (17.52) } \\
\text { Clay }(73.06)\end{array}$ & Clay & - \\
\hline
\end{tabular}

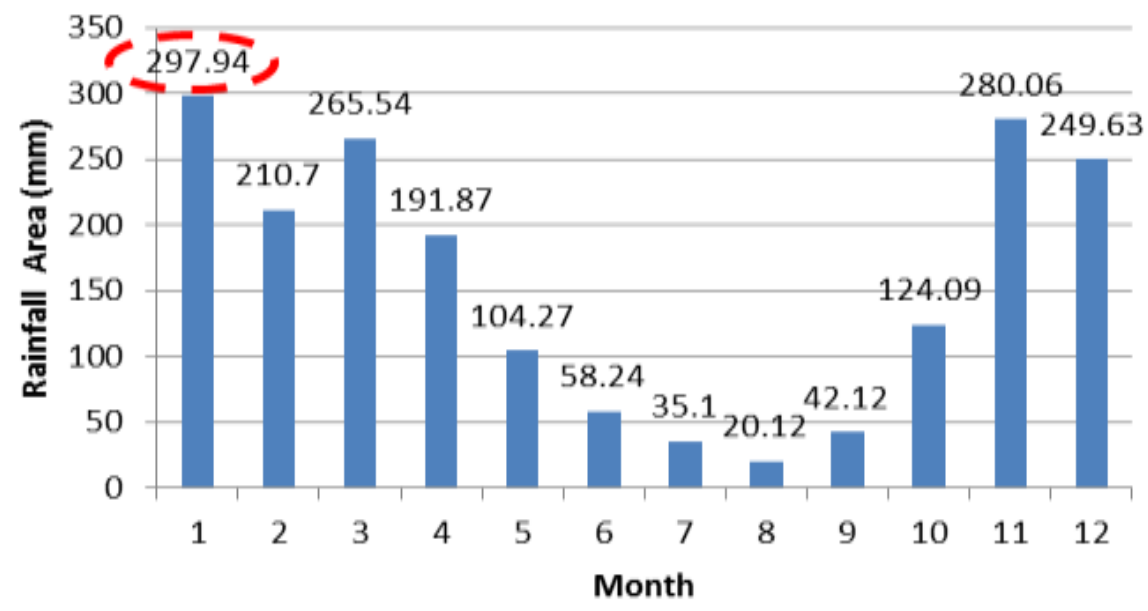

Fig. (2). Average annual rainfall at research center.

\section{Topography Conditions}

Aerial photo map was processed to obtain the map of DEM (Digital Elevation Model) and DSM (Digital Surface Model) with a contour interval of 2 meters. Table (2) shows that the distribution of the land area had a slope that dominated the area between the ramps to steep. Land use in the study area could result in steep inclined erosion and surface runoff that will interfere with the quality of runoff.

Egyptian J. Desert Res., 65, No. 1, 1-10 (2015) 
Table (2). Distribution of the slope of the land area.

\begin{tabular}{ccc}
\hline Elevation range & Remarks & Area (Ha) \\
\hline $0-8$ & Flat & 0.046 \\
$8-15$ & Gently sloping & 0.521 \\
$15-25$ & Rather steep & 0.995 \\
$25-40$ & Steep & 0.512 \\
$40-100$ & Extremely steep & 0.070 \\
\multicolumn{2}{c}{ Total area (Ha) } & 2.144 \\
\hline
\end{tabular}

\section{Actual Runoff Measurement and Runoff Coefficient}

The measurements of the actual runoff from the research area were recorded every rain event (30 measurements). Table (3) shows the results of actual measurement, which was the greatest amount of runoff occurred at Plot $5\left(3087.98 \mathrm{dm}^{3}\right)$, followed by Plot $2\left(3037.72 \mathrm{dm}^{3}\right)$, while the smallest amount of runoff occurred at Plot $3\left(1736.35 \mathrm{dm}^{3}\right)$. These results are in consistence with the theoretical statement that the smallest amount of runoff coefficient value is on forest plant (near zero), or in other words the volume of rain almost entirely for infiltration. That is because the forest stands or annual plants have high infiltration capacity, comparable to the rooting depth of plant.

Table (3). Actual runoff neasurement.

\begin{tabular}{|c|c|c|c|c|}
\hline \multirow{2}{*}{$\begin{array}{c}\text { Plot } \\
\text { number }\end{array}$} & \multirow[b]{2}{*}{ Crop pattern } & \multirow{2}{*}{$\begin{array}{c}\text { Slope } \\
(\%)\end{array}$} & \multicolumn{2}{|c|}{ Total runoff } \\
\hline & & & $\begin{array}{l}\text { Per plot } \\
\text { (1/plot) }\end{array}$ & $\begin{array}{c}\text { Per meter } \\
\text { square }\left(\mathbf{l} / \mathbf{m}^{2}\right)\end{array}$ \\
\hline 1 & Rubber & 12 & 1896.21 & 0.90 \\
\hline 2 & $\begin{array}{l}\text { Coconut + seasonal } \\
\text { crop }\end{array}$ & 21 & 3037.72 & 34.52 \\
\hline 3 & Seasonal crop & 18 & 1736.35 & 26.31 \\
\hline 4 & $\begin{array}{l}\text { Coconut + seasonal } \\
\text { crop }\end{array}$ & 23 & 2662.51 & 40.34 \\
\hline 5 & Seasonal crop & 22 & 3087.98 & 46.79 \\
\hline
\end{tabular}

Theoretically, the steeper the slope, the higher runoff that occurs, but this does not occur in the present study. For instance, the 23\% slope runoff was $40.34 \mathrm{l} / \mathrm{m}^{2}$, while at $22 \%$ slope; runoff that occurs was $46.79 \mathrm{l} / \mathrm{m}^{2}$. This is because the plot 4 using multiple cropping patterns between coconut and seasonal crop, which affects the extent of crop canopy, while the plot 5 (slope $22 \%$ ) only use seasonal crop patterns. 
Based on the measurement, results that can be calculated from runoff coefficient for each plot were tested. Runoff coefficient calculated from actual runoff and rainfall based on observations of runoff during the research field is shown in table (4). From table (4) it can be concluded that from the research results, rubber plant had a runoff coefficient (C) of 0.001 , while the multiple cropping between coconut plant and seasonal crops was higher than other cropping patterns. The pattern of coconut intercropping with seasonal plants showed that the value of $\mathrm{C}$ was higher than other cropping patterns. These results are in agreement with the theory that the runoff coefficient is influenced by land use, especially shade canopy of plants (Bafdal et al., 2011).

Table (4). Values of runoff coefficient in the research center area.

\begin{tabular}{clcc}
\hline No. & \multicolumn{1}{c}{ Land use } & Area $\left(\mathbf{m}^{2}\right)$ & $\begin{array}{c}\text { Runoff } \\
\text { coefficient }(\mathbf{C})\end{array}$ \\
\hline 1 & Rubber & 3,000 & 0.001 \\
2 & Agriculture Area & & \\
& Coconut + Seasonal Crop & 6,742 & 0.051 \\
& Seasonal Crop & 6,936 & 0.047 \\
& Runoff Coefficient Average & 16,678 & $\mathbf{0 . 0 4 0}$ \\
\hline
\end{tabular}

\section{Potential Runoff}

Prediction of the amount of runoff calculation is done using the theoretical equation of Rational Method and calculated from runoff coefficient multiplied by the monthly rainfall and catchment area. In the present research, runoff occurred in the dry season (monthly rainfall of less than $100 \mathrm{~mm}$ ) is considered zero, it's based on the research of Bafdal et al. (2011), which reported that in the dry season runoff does not occur on agricultural land.

The results of the analysis of runoff theoretically demonstrated that the largest surface runoff occurred in January with the amount of $200.46 \mathrm{~m}^{3}$, this is in line with the peak rainfall occurs in January (Table 5). Total cumulative runoff values obtained for the year was $1160.05 \mathrm{~m}^{3}$, this result suggests that runoff is potentially used as an alternative source of irrigation water in the dry land.

\section{Design of Runoff Management Integrated Farming}

The rainwater harvesting system consists of a water catchment zone (water collector) and the cultivation zone (reservoir, concentration). The relationship between these two zones, in terms of size extent, determines the amount of rainfall multiplier factor. To design a system properly, it is advisable to determine the ratio between catchment zones ( $\mathrm{C}$, or Catchment) to cultivation zone (CA or Cultivated Area).

Egyptian J. Desert Res., 65, No. 1, 1-10 (2015) 
Design of Runoff Management Integrated Farming in this research was conducted to determine or delineate the catchment area, the cultivation areas, and determine the location of water reservoirs (storage). Catchment area zone was determined on the upstream area or steeply-slope areas, while the area of cultivation, which will be used in the experiment, is downstream where the land has a slope that is relatively flat or gently sloping and the water reservoir (storage) is, therefore, placed between the catchment area and the area of cultivation. The runoff results are based on 5 runoff plots within the boundary shown in fig. (3).

Table (5). Analysis of potential runoff using rational method.

\begin{tabular}{lccc} 
Month & $\begin{array}{c}\text { Rainfall depth } \\
(\mathbf{m m})\end{array}$ & $\begin{array}{c}\text { Runoff } \\
\left(\mathbf{m}^{\mathbf{3}}\right)\end{array}$ & $\begin{array}{c}\text { Cumulative runoff } \\
\left(\mathbf{m}^{\mathbf{3}}\right)\end{array}$ \\
\hline January & 297.94 & 200.46 & 200.46 \\
February & 210.70 & 141.77 & 342.23 \\
March & 265.54 & 178.67 & 520.90 \\
April & 191.87 & 129.10 & 650.00 \\
May & 104.27 & 70.16 & 720.16 \\
June* & 58.24 & 0.00 & 720.16 \\
July* & 35.10 & 0.00 & 720.16 \\
August* & 20.12 & 0.00 & 720.16 \\
September* & 42.12 & 0.00 & 720.16 \\
October & 124.09 & 83.49 & 803.65 \\
November & 280.06 & 188.44 & 992.08 \\
December & 249.63 & 167.96 & 1160.05 \\
\hline
\end{tabular}

*) Dry month (monthly rainfall $<100 \mathrm{~mm}$ ) 


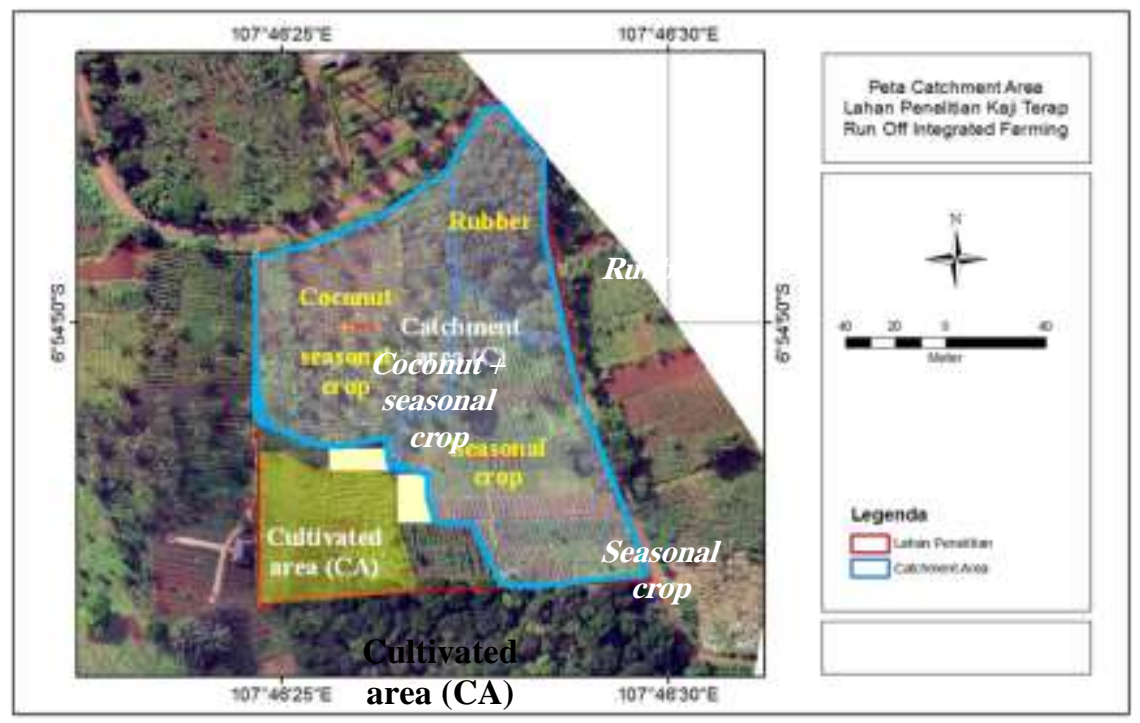

Fig. (3). Design of runoff management integrated farming.

\section{C: CA ratio analysis}

To determine the ratio of $\mathrm{C}$ : $\mathrm{CA}$, the data required were crop water requirements, rainfall design, runoff coefficient and the efficiency factor. The basic principle in determining the ratio catchment: cultivated area (C: CA) was as follows:

1. Water is needed in the area of cultivation $(\mathrm{CA})=$ Water harvested in the catchment $(\mathrm{C})$

2. Water is needed in the area of cultivation $(\mathrm{CA})=$ [crop water requirement - rainfall design] $\times \mathrm{A}_{\mathrm{CA}}\left(\mathrm{m}^{2}\right)$

3. Water is harvested in the catchment $(C)=$ runoff coefficient $\times$ rainfall design $\times$ efficiency factor $x A_{C}\left(m^{2}\right)$

4. Thus, the ratio of the $\mathrm{C}: \mathrm{CA}=$ (crop water requirement - rainfall design) / (runoff coefficient $\mathrm{x}$ rainfall design $\mathrm{x}$ efficiency factor).

\section{Crop Water Requirement}

To calculate the crop water requirement, it is assumed that land cultivation with corn for three seasons of the year and the period of growing corn in a single growing season of 120 days, then the value of the crop water requirement is estimated as follows: Crop water requirement $=$ Potential evapotranspiration $\mathrm{x}$ crop coefficients $\mathrm{x}$ 120 days $\mathrm{x} 3$ times planting

For example, potential evapotranspiration by an average of $4 \mathrm{~mm} /$ day and an average corn crop coefficients during the growth period is 0.82 , then:

Egyptian J. Desert Res., 65, No. 1, 1-10 (2015) 
Crop water requirement $=4 \mathrm{~mm} /$ day $\times 120$ days $\times 0.82 \times 3=1180.80 \mathrm{~mm}$ The results show that the amount of the cumulative runoff in the year of $1160.05 \mathrm{~mm}$ would be able to meet the water requirements for corn crop planting 3 times a year.

\section{Rainfall Design}

To create a rainwater harvesting system, the quantity of rainfall during the growing season should be known. The quantity of rain, which is used as a basis for designing a rainwater harvesting system is commonly referred to as "design rainfall". For agricultural needs, design rainfall used is usually in the form of annual precipitation with a probability of at least $80 \%$ exceeded the prescribed manner (Dwiratna, 2010):

1. Sorting monthly rainfall data from smallest to largest value

2. Calculating the rainfall probability with the equation

$P(\%)=\frac{m-0.375}{n+0.25} \times 100$

Where: $\mathrm{p}=$ Rainfall probability (\%),

$\mathrm{m}=$ the order of the data with $\mathrm{m}=1$ for the largest rainfall data,

and

$\mathrm{n}=$ the number of data used rain

Based on rainfall data used, the value of design rainfall with a probability of $80 \%$ is exceeded by $911.05 \mathrm{~mm}$.

\section{Runoff Coefficient and Efficient Factors}

A runoff coefficient value in the study area is divided into three types of land use that is the rubber, coconut + seasonal crops and seasonal crops area. Based on table (4), the average of runoff coefficient that was obtained by direct measurement in the catchment area was 0.04 .

Part of the harvest rainwater, which can be used by plants is called "Efficiency Factor". Higher efficiency was obtained when processing leveled and flat land area. This efficiency factor was ranging between 0.5 and 0.75 , in this case the value of the efficiency factor in the study area was assumed to be 0.5 (Critchley and Claus, 1991).

\section{Ratio of C: CA} follows:

Based on the above parameters, the ratio of $\mathrm{C}$ : $\mathrm{CA}$ was calculated as

$$
\mathrm{C}: \mathrm{CA}=\frac{(\text { Crop water requiremen } \mathrm{t}-\text { Rainfall design })}{\text { (Runoff Coefficient } \mathrm{x} \text { Rainfall Design } \mathrm{x} \text { Efficiency Factor })}
$$




$$
\mathrm{C}: \mathrm{CA}=\frac{(1180.80 \mathrm{~mm}-911.05 \mathrm{~mm})}{(0.04 \times 911.05 \mathrm{~mm} \times 0.5)}=14.80
$$

Value C: CA of 14.8 indicates that to meet the water needs of maize crop in an area of 1000 meter square for 3 seasons per year, a catchment area of 14800 meter square is needed.

\section{CONCLUSION}

Based on the research results, it could be concluded that:

1. The results of the analysis showed that the theoretical runoff using Rational Method occurred in January is the amount of 200.46 cubic meters; in line with the peak rainfall $(297.94 \mathrm{~mm})$ occurred at the research area in Jatinangor Campus.

2. The cumulative runoff value obtained for the year is 1160.05 cubic meters; this suggests that runoff is potential to use as an alternative source of irrigation water in the dry land.

3. Analysis of the ratio of Catchment Area to Cultivated Area showed the value of the C: CA of 14.8. The water need of maize crop on an area of 1000 meter square for 3 seasons per year is from the catchment area of 14800 meter square.

\section{REFERENCES}

Critchley, W. and S. Claus (1991). Water Harvesting. A Manual for the Design and Construction of Water Harvesting Schemes for Plant Production. Food and Agriculture Organization of the United Nations-Rome, Italy.

Dwiratna, Sophia (2010). Monthly rainfall stochastic model and its application in schedule and planting pattern determination of dryland farming in Bandung Regency. Research Report, University of Padjadjaran, Bandung.

Bafdal, Nurpilihan, Dwiratna N.P. Sophia and A. Kharistya (2013). Assess the applicability of runoff management integrated farming to improve productivity and capability. Dryland Research Report, University of Padjadjaran, Bandung.

Bafdal, Nurpilihan, E. Suryadiand and A. Kharistya (2011). Calculation runoff on a steep land hybrid corn planted. Padjadjaran DR. Research Report, University of Padjadjaran, Bandung.

Prinz, D. and A.H. Malik (2002). Runoff Farming. Institute of Water Resources Management, Hydraulic and Rural Engineering, Germany. 